\title{
Massive Acetaminophen Overdose
}

\author{
Thor S. Stead ${ }^{1}$, Jae Yun Jeong ${ }^{2}$, Latha Ganti ${ }^{3,4,5}$, Jose Rubero ${ }^{6}$ \\ 1. Emergency Medicine, Alpert Medical School of Brown University, Providence, USA 2. Biochemistry \& Molecular \\ Biology, Brown University, Providence, USA 3. Emergency Medicine, Envision Physician Services, Nashville, USA 4. \\ Emergency Medicine, University of Central Florida College of Medicine/Hospital Corporation of America Graduate \\ Medical Education Consortium of Greater Orlando, Orlando, USA 5. Emergency Medical Services, Polk County Fire \\ Rescue, Bartow, USA 6. Emergency Medicine, University of Central Florida College of Medicine, Orlando, USA
}

Corresponding author: Latha Ganti, latha.ganti@ucf.edu

\begin{abstract}
The authors present a case of a fatal intentional acetaminophen (APAP) overdose and remind the physician how ubiquitous the drug is. This case presentation highlights the clinical presentation and treatment options for APAP overdose in unresponsive patients. In cases of massive APAP overdose (> $300 \mu \mathrm{g} / \mathrm{ml}$ plasma at four hours post-ingestion), prompt administration of $\mathrm{N}$-acetylcysteine (NAC) and early hemodialysis are indicated.
\end{abstract}

Categories: Emergency Medicine

Keywords: acetaminophen, toxicology, poisoning

\section{Introduction}

Acetaminophen (APAP) is the most widely used over-the-counter pain reliever and antipyretic medication around the world [1,2]. However, high doses of APAP are hepatotoxic and are the most common cause of drug-induced liver failure in the United States (US) [3-5]. APAP overdoses in the United States account for $50,000 \mathrm{ED}$ visits per year, over 10,000 hospitalizations, and approximately 100 deaths [2]. The majority of APAP overdose cases are a result of intentional self-harm; however, overdose can also be due to a lack of consumer knowledge. Unintentional overdoses often occur because the victim was unaware that APAP was an ingredient in a combination drug they were taking or because of the belief that over-the-counter drugs are universally benign [5]. If APAP overdose is caught early (< eight hours after ingestion), it is usually reversible via gastric decontamination and administration of the antidote $\mathrm{N}$-acetylcysteine (NAC) $[6,7]$.

Received 07/02/2020 Review began $07 / 08 / 2020$ Review ended 07/09/2020 Published 07/18/2020

\section{() Copyright 2020}

Stead et al. This is an open access article distributed under the terms of the Creative Commons Attribution License CC-BY 4.0., which permits unrestricted use, distribution, and reproduction in any medium, provided the original author and source are credited.

\section{Case Presentation}

A 53-year-old male with unknown past medical history was brought in via ambulance after his neighbor called due to the patient being unresponsive. The patient was found by emergency medical services (EMS) with multiple bottles of empty acetaminophen around him on the bathroom floor and self-inflicted wounds on his wrist suggestive of a possible suicide attempt. He was in cardiac arrest with pulseless electrical activity (PEA). He received naloxone en route by the paramedics. Return of spontaneous circulation (ROSC) was achieved within 10 minutes of cardiopulmonary resuscitation. He had agonal breathing and pupils that were $3 \mathrm{~mm}$, round, and sluggish bilaterally.

Upon arrival at the ED, the patient was started on vasopressors and intubated. In the ED, the temperature was $89.9^{0} \mathrm{~F}$, with a mean arterial pressure of $50 \mathrm{mmHg}$ on norepinephrine infusion, a pulse between 90 and 100 beats per minute, a respiratory rate of 20 (ventilator rate), and oxygen saturation of $94 \%$ on $100 \%$ FiO2. Laboratory analysis was remarkable for a white blood cell count of $33 \times 103 / \mathrm{mm}^{3}$ with neutrophilic predominance. Hepatic panel showed transaminitis with aspartate aminotransferase 1256 units/L (normal range 10-37) and alanine aminotransferase 232 units/L (normal range 12-78). Lactic acid level was $12 \mathrm{mg} / \mathrm{dL}$. The patient had an anion gap metabolic acidosis with bicarbonate of $11 \mathrm{mmol} / \mathrm{L}$, and evidence of acute kidney injury (AKI), with serum creatinine $7 \mathrm{mg} / \mathrm{dL}$ and creatine protein kinase $>1000 \mathrm{units} / \mathrm{L}$. Arterial blood gas revealed a $\mathrm{pH}$ of $6.88, \mathrm{CO}_{2}$ of $51 \mathrm{mmHg}, \mathrm{pO}_{2}$ of $259 \mathrm{mmHg}$. The patient had an elevated troponin of 35 $\mathrm{ng} / \mathrm{mL}$, but cardiac echocardiogram revealed a normal left ventricular ejection fraction of $55 \%$ (Tables $1-4$ ). 


\section{Cureus}

WBC $\left(4.0-12.0 \mathrm{~K} / \mathrm{mm}^{3}\right)$

32.82 * $\mathrm{H}$

$\operatorname{RBC}\left(4.6-6.0 \mathrm{M} / \mathrm{mm}^{3}\right)$

4.66

$\mathrm{Hgb}(14.0-18.0 \mathrm{gm} / \mathrm{dL})$

Hct (42.0 - $52.0 \%)$

43.4

$\operatorname{MCV}(80.0-100.0 \mathrm{fL})$

93.1

$\mathrm{MCH}(27.0-31.0 \mathrm{pg})$

30.7

MCHC (32 - $37.5 \mathrm{~g} / \mathrm{dL})$

32.9

RDW (12.0 - $14.0 \%)$

$14.1 \mathrm{H}$

PIt Count $\left(130-400 \mathrm{~K} / \mathrm{mm}^{3}\right)$

282

$\operatorname{MPV}(7.0-10.0 \mathrm{fL})$

Segmented Neutrophils (38.0 - $74.0 \%$ )

69

Band Neutrophils (5.0 - $11.0 \%)$

$14 \mathrm{H}$

Lymphocytes (20 - $45 \%$ )

$6 L$

Monocytes (3 - $10 \%)$

10

Atypical Lymphocytes (0 - $1 \%)$

1

\section{TABLE 1: Complete blood count profile}

WBC, white blood cell count; RBC, red blood cell count; Hgb, hemoglobin; Hct, hematocrit; MCV, mean corpuscular volume; MCH, mean corpuscular hemoglobin; MCHC, mean corpuscular hemoglobin concentration; RDW, red cell distribution width; MPV, mean platelet volume 


\section{Cureus}

\begin{tabular}{l|l} 
Sodium (136 - $145 \mathrm{mmol} / \mathrm{L})$ & $148 \mathrm{H}$
\end{tabular}

$\begin{array}{ll}\text { Potassium }(3.7-5.1 \mathrm{mmol} / \mathrm{L}) & 3.5 \mathrm{~L}\end{array}$

$\begin{array}{ll}\text { Chloride }(98-107 \mathrm{mmol} / \mathrm{L}) & 102\end{array}$

$\begin{array}{ll}\text { Carbon Dioxide (21 - } 32 \mathrm{mmol} / \mathrm{L}) & 11 \mathrm{~L}\end{array}$

$\begin{array}{ll}\text { Anion Gap } & 38.5\end{array}$

BUN $(7-18 \mathrm{mg} / \mathrm{dL}) \quad 30 \mathrm{H}$

$\begin{array}{ll}\text { Creatinine }(0.55-1.3 \mathrm{mg} / \mathrm{dL}) & 4.30 \mathrm{H}\end{array}$

$\begin{array}{ll}\text { Estimated GFR mL/min } & 15\end{array}$

BUN/Creatinine Ratio $\quad 7$

$\begin{array}{ll}\text { Glucose }(74-106 \mathrm{mg} / \mathrm{dL}) & 176 \mathrm{H}\end{array}$

$\begin{array}{ll}\text { Calcium }(8.4-10.1 \mathrm{mg} / \mathrm{dL}) & 7.2 \mathrm{~L}\end{array}$

$\begin{array}{ll}\text { Magnesium (1.8 - } 2.5 \mathrm{mg} / \mathrm{dL}) & 7.2 \mathrm{H}\end{array}$

$\begin{array}{ll}\text { Total Bilirubin }(0.2-1.5 \mathrm{mg} / \mathrm{dL}) & 2.7 \mathrm{H}\end{array}$

$\begin{array}{ll}\text { AST }(10-37 \text { unit/L) } & 1256 \mathrm{H}\end{array}$

$\begin{array}{ll}\text { ALT (12 - } 78 \text { unit/L) } & 232 \mathrm{H}\end{array}$

Total Alk Phosphatase (45 - 117 unit/L) $\quad 89$

$\begin{array}{ll}\text { Total Protein }(6.4-8.2 \mathrm{~g} / \mathrm{dL}) & 6.2 \mathrm{~L}\end{array}$

$\begin{array}{ll}\text { Albumin }(3.4-5.0 \mathrm{~g} / \mathrm{dL}) & 3.6\end{array}$

\section{TABLE 2: Chemistry profile}

BUN, blood urea nitrogen; GFR, glomerular filtration rate; AST, aspartate aminotransferase; ALT, alanine aminotransferase 


\section{Cureus}

\begin{tabular}{|lc}
\hline Puncture site & R Radia \\
\hline POC ABG pH $(7.35-7.45)$ & $6.88 \mathrm{~L}$ \\
POC ABG pCO2 $(35-45 \mathrm{mmHg})$ & $51.8 \mathrm{H}$ \\
POC ABG pO2 $(80-105 \mathrm{mmHg})$ & $259 \mathrm{H}$ \\
ABG PO2/FiO2 Ratio & 259 \\
POC ABG HCO3 $(22-26 \mathrm{mmol} / \mathrm{L})$ & $9.7 \mathrm{~L}$ \\
ABG Total CO2 $(23-27 \mathrm{mmol} / \mathrm{L})$ & $11 \mathrm{~L}$ \\
ABG O2 Saturation $(95-98 \%)$ & $99 \mathrm{H}$ \\
POC ABG Base Excess $(-2-3 \mathrm{mmol} / \mathrm{L})$ & $-23 \mathrm{~L}$ \\
Allen Test & Pass \\
Set Respiration Rate $(/ \mathrm{min})$ & 20 \\
O2 Delivery Device & Vent \\
Vent Mode & $\mathrm{CMV}$ \\
POC FiO2 (\%) & 100 \\
Tidal Volume (mL) & 500 \\
POC PEEP (cmH2O) & 5
\end{tabular}

\section{TABLE 3: Arterial blood gas}

POC ABG, point-of-care arterial blood gas test

\begin{tabular}{|l|l}
\hline Opiates & Negative \\
\hline Methadone & Negative \\
Barbituates & Negative \\
Phencyclidine & Negative \\
Amphetamines & Negative \\
Benzodazepines & Negative \\
Cocaine & Negative \\
Cannabinoids & Negative \\
Acetaminophen $(10-30 \mathrm{mcg} / \mathrm{ml})$ & $>300$ *H \\
Alcohol, Quantitative $(<5.0 \mathrm{mg} / \mathrm{dl})$ & $<3 \mathrm{~L}$ \\
Salicylates $(4-20 \mathrm{mg} / \mathrm{dL})$ & 4.8
\end{tabular}

\section{TABLE 4: Toxicology screen}

The acetaminophen level was $>300 \mathrm{mcg} / \mathrm{mL}$ (normal range 10-30). Toxicology screen was negative for cocaine, barbiturates, methadone, phenylcyclidine, amphetamines benzodiazepines, or cannabinoids. Foley insertion revealed anuria since admission. Chest radiograph revealed mild bilateral perihilar airspace opacities (Figure 1). 


\section{Cureus}

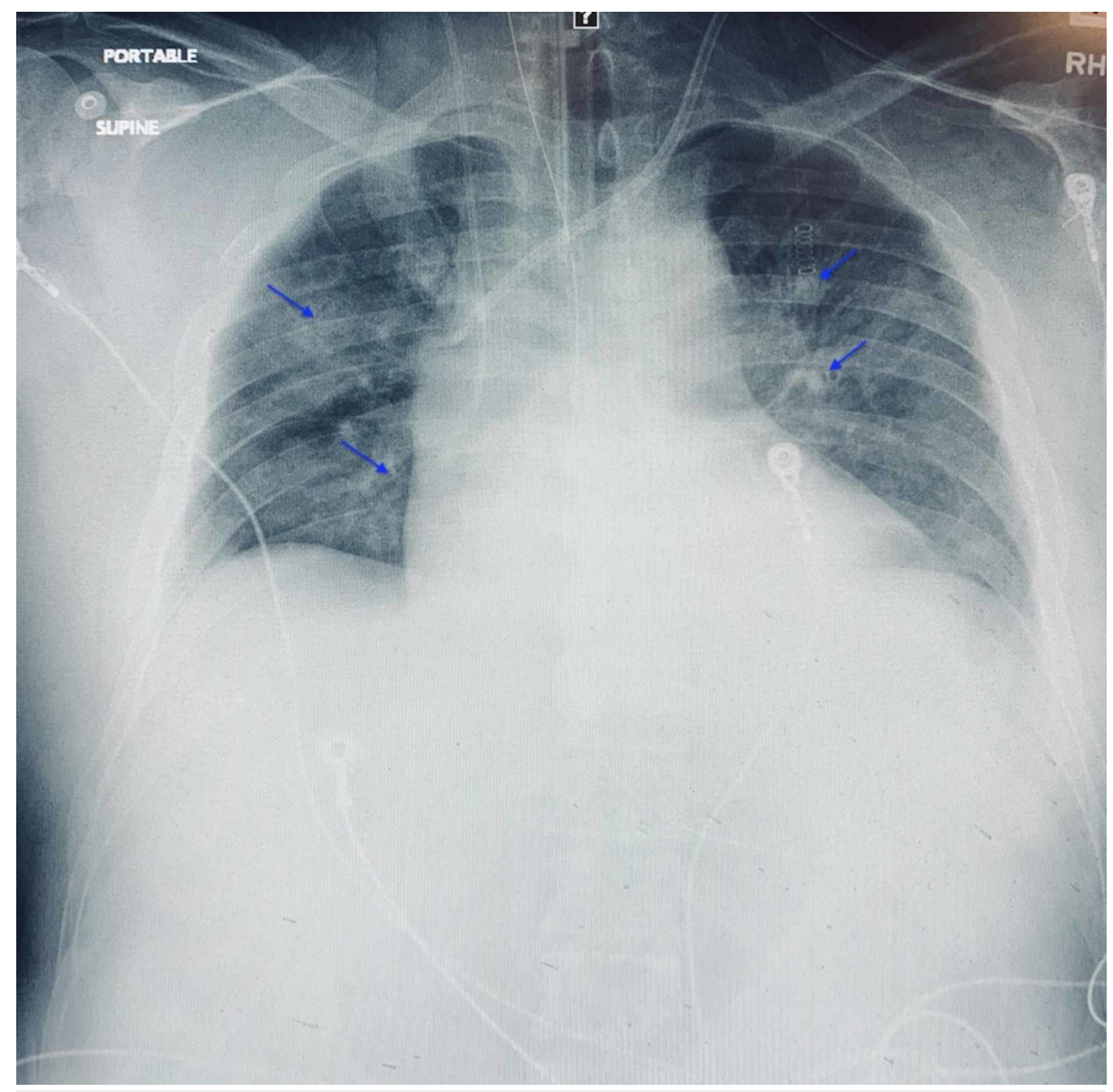

\section{FIGURE 1: Chest radiograph demonstrating mild bilateral perihilar airspace opacities (arrows)}

A central line was placed in the right internal jugular vein, a trialysis catheter placed in the left internal jugular vein, and a right femoral arterial line was placed. The poison control center was called and NAC was initiated. Four ampules of bicarbonate were given and a bicarbonate infusion was started. Additional pressors including vasopressin, epinephrine, and neosynephrine were required. Active body warming was initiated and nephrology was consulted for continuous renal replacement therapy (CRRT). Aggressive intravenous fluids were initiated (>4L) without significant improvement. Approximately 12 hours later, the patient went into cardiopulmonary arrest and expired.

\section{Discussion}

APAP is primarily metabolized by adding a glucuronide or sulfate to the hydroxyl group, forming nontoxic mercaptate conjugates that are excreted. Above the toxic threshold, APAP administration produces NAPQI (N-acetyl-p-benzoquinoneimine), a toxic compound which binds proteins, resulting in hepatocyte necrosis. This occurs when glutathione concentration within the liver decreases to $<30 \%$ of normal levels [5].

The range of symptoms in APPA overdose can be grouped into four stages (Figure 2). 


\section{Cureus}

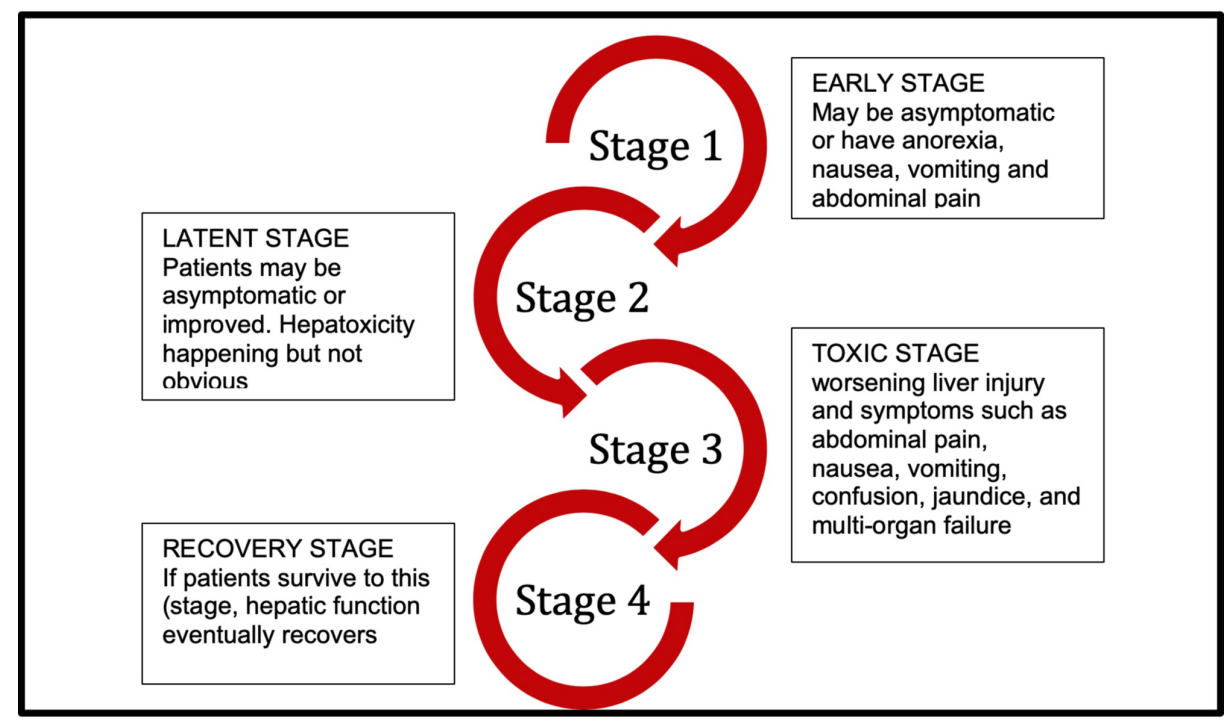

FIGURE 2: Stages of acetaminophen toxicity

Interventions for APAP overdose include gastrointestinal decontamination through oral activated charcoal, NAC administration, and dialysis (Figure 3). 


\section{Cureus}

\section{Acetaminophen Overdose:}

Treatment Options
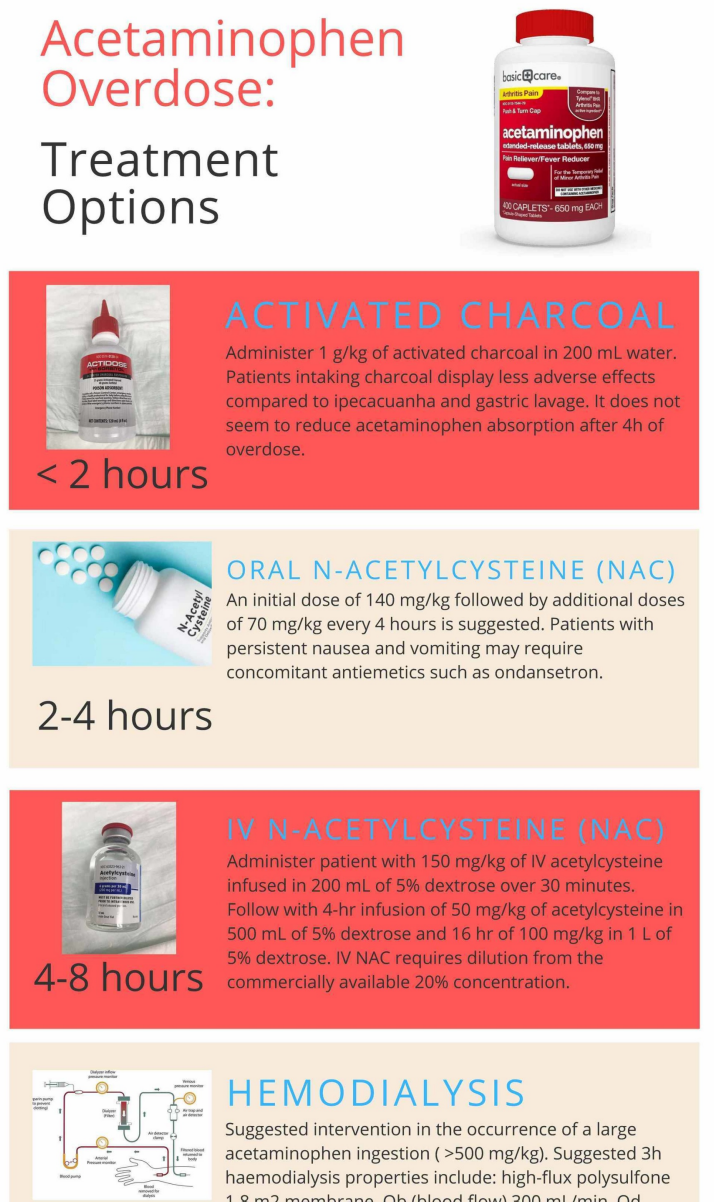

HEMODIALYSIS

Suggested intervention in the occurrence of a large acetaminophen ingestion ( $>500 \mathrm{mg} / \mathrm{kg}$ ). Suggested $3 \mathrm{~h}$ haemodialysis properties include: high-flux polysulfone

8-24 hours $18 \mathrm{~m} 2$ membrane, Qb (blood flow) $300 \mathrm{~mL} / \mathrm{min}$, Qd
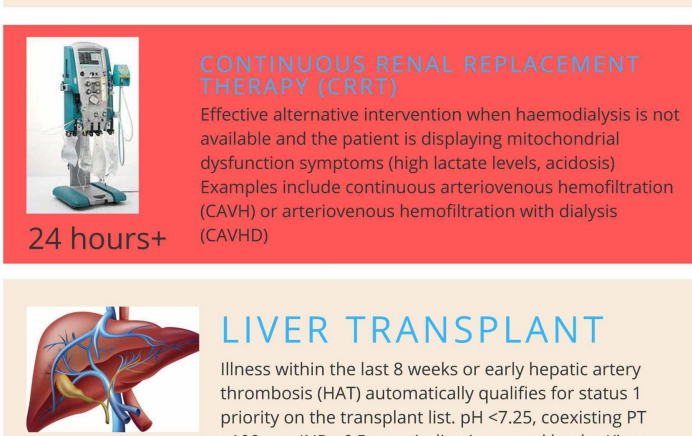

LIVER TRANSPLANT

IIIness within the last 8 weeks or early hepatic artery thrombosis (HAT) automatically qualifies for status priority on the transplant list. $\mathrm{pH}<7.25$, coexisting PT $>100 \mathrm{~s}$ or INR $>6.5 \mathrm{~s}$ are indications used by the Kings

Liver Failure

necessity.

\section{FIGURE 3: Acetaminophen poisoning treatment options}

Activated charcoal should only be given if the ingestion occurred within the last two hours. It is administered as $1 \mathrm{~g} / \mathrm{kg}$ of active charcoal in $200 \mathrm{~mL}$ water. NAC is available in both oral and intravenous formulations. In the ED, the IV formulations are most commonly used. IV NAC is given as $150 \mathrm{mg} / \mathrm{kg}$ infused in $200 \mathrm{~mL}$ of $5 \%$ dextrose over $30 \mathrm{~min}$, followed by a four-hour infusion of $50 \mathrm{mg} / \mathrm{kg}$ of acetylcysteine in $500 \mathrm{~mL}$ of $5 \%$ dextrose and a 16 -hour of $100 \mathrm{mg} / \mathrm{kg}$ in $1 \mathrm{~L}$ of $5 \%$ dextrose. If serum APAP concentration is $<10$ micrograms $/ \mathrm{mL}$ and transaminase concentrations are normal, then acetylcysteine therapy can be discontinued and discharge can be considered [5].

Treatment threshold for NAC antidote treatment is based on the Rumack-Matthew nomogram which plots APAP levels against time (Figure 4). 


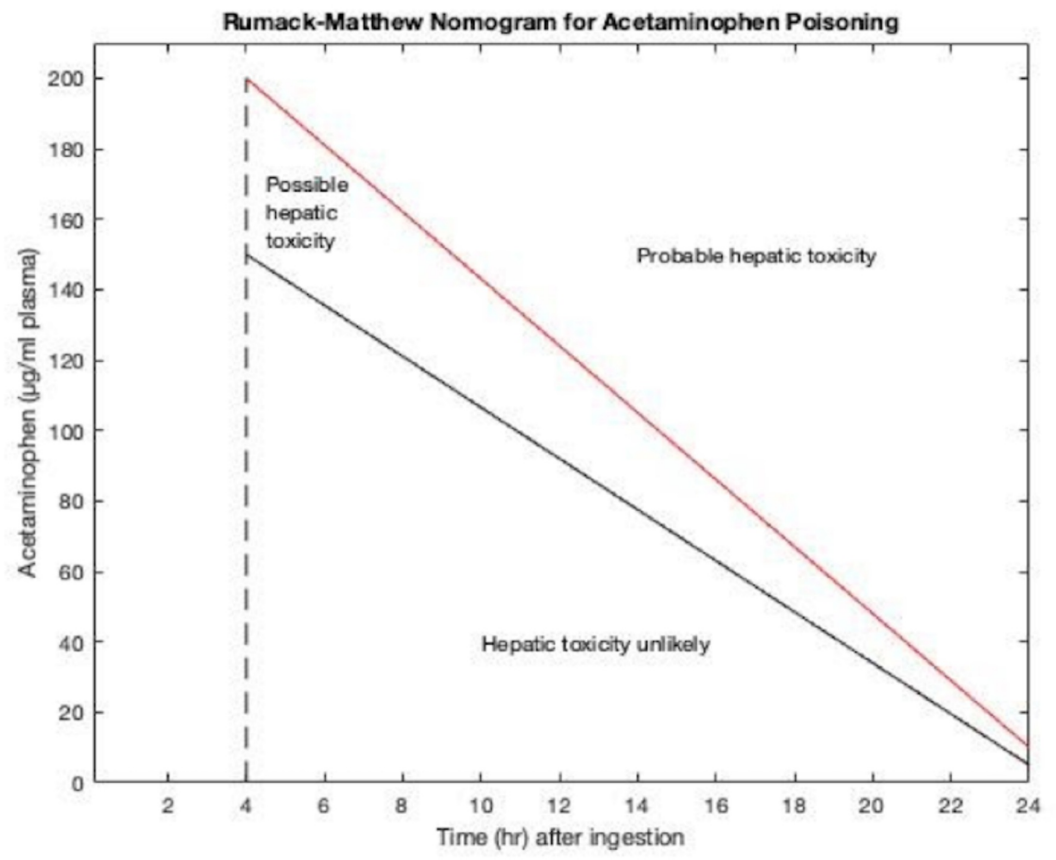

FIGURE 4: Acetaminophen nomogram adapted from Rumack BH, Matthew H: Pediatrics 55:871, 1975

Recent studies show that IV NAC treatment administered at lower doses reduces potential side effects such as nausea and allergy [8]. Hemodialysis is recommended for patients with extreme plasma acetaminophen concentrations (> $200 \mu \mathrm{g} / \mathrm{mL}$ plasma at four hours post-ingestion) or displaying symptoms of mitochondrial dysfunction such as elevated lactate levels and acidosis $[9,10]$. CRRT is also suggested in severe cases in which patients display neurological, respiratory, or circulatory malfunctioning (encephalopathy or coma) as our patient did [11].

Patients lacking glutathione reserves such as those with chronic alcohol use are especially at risk, but prompt acetylcysteine administration can effectively prevent acute liver failure. Our patient had likely overdosed the night prior given he arrived in multiorgan failure with irreversible damage to the liver. The patient had an acetaminophen level more than 10x normal. Other complications such as cardiac arrest, respiratory failure, rhabdomyolysis, and septic shock developed, rendering interventions ineffective.

Growth factors such as hepatocyte growth factor (HGF) are known to be crucial in liver regeneration, a continuous interest amongst researchers in their therapeutic application. However, higher concentrations of HGF in plasma were found in nonsurvivors as opposed to survivors, suggesting that interventions via other factors such as c-Met or TGF- $\beta$ may be more effective for treatment [12]. In survivors, liver function is normally regained within three months.

\section{Conclusions}

This case demonstrates the evaluation and management of late-stage APAP overdose in an unresponsive patient. Key takeaways include the rapid administration of CRRT in the presence of renal failure, administration of pressors for hypotension, IV NAC dosed according to the APAP nomogram, and intubation if unresponsive.

\section{Additional Information}

\section{Disclosures}

Human subjects: Consent was obtained by all participants in this study. HCA Centralized Algorithms for Research Rules on IRB Exemptions (CARRIE)/ IRB manager issued approval 2020-479. Based on the information provided and attested as true, the research plan described does not require IRB oversight. This is because you are either a) not engaging in research with human subjects as defined by federal regulations; b) engaging in research with human subjects deemed excluded from IRB oversight per 45CFR46.102(l) OR c) engaging in research with sufficient human subject protections in the design to meet one or more IRB exemption criteria set forth in 45CFR46.104. Conflicts of interest: In compliance with the ICMJE uniform disclosure form, all authors declare the following: Payment/services info: All authors have declared that no 
financial support was received from any organization for the submitted work. Financial relationships: All authors have declared that they have no financial relationships at present or within the previous three years with any organizations that might have an interest in the submitted work. Other relationships: All authors have declared that there are no other relationships or activities that could appear to have influenced the submitted work.

\section{Acknowledgements}

This research was supported (in whole or in part) by HCA Healthcare and/or an HCA Healthcare affiliated entity. The views expressed in this publication represent those of the author(s) and do not necessarily represent the official views of HCA Healthcare or any of its affiliated entities.

\section{References}

1. Nourjah P, Ahmad SR, Karwoski C, Willy M: Estimates of acetaminophen (paracetomal)-associated overdoses in the United States. Pharmacoepidemiol Drug Saf. 2006, 15:398-405. 10.1002/pds.1191

2. Lee, WM: Acetaminophen (APAP) hepatotoxicity-isn't it time for APAP to go away? . J Hepatol. 2017, 67:1324-1331. 10.1016/j.jhep.2017.07.005

3. Larson AM, Polson J, Fontana RJ, et al.: Acetaminophen-induced acute liver failure: results of a United States multicenter, prospective study. Hepatology. 2005, 42:1364-1372. 10.1002/hep.20948

4. Yoon E, Babar A, Choudhary M, Kutner M, Pyrsopoulos P: Acetaminophen-induced hepatotoxicity: a comprehensive update. J Clin Transl Hepatol. 2016, 4:131-142. 10.14218/JCTH.2015.00052

5. Wightman RS, Nelson LS: Acetaminophen. Tintinalli's Emergency Medicine: A Comprehensive Study Guide, 9e. Tintinalli JE, Ma O, Yealy DM, Meckler GD, Stapczynski J, Cline DM, Thomas SH. (ed): McGraw-Hill, New York, NY; 2020. 1:

6. Mazaleuskaya LL, Sangkuhl K, Thorn CF, FitzGerald GA, Altman RB, Klein TE: PharmGKB summary: pathways of acetaminophen metabolism at the therapeutic versus toxic doses. Pharmacogenet Genomics. 2015, 25:416-426. 10.1097/fpc.0000000000000150

7. Hodgman MJ, Garrard AR: A review of acetaminophen poisoning . Crit Care Clin. 2012, 28:499-516. 10.1016/i.ccc.2012.07.006

8. Chiew AL, Gluud C, Brok J, Buckley NA: Interventions for paracetamol (acetaminophen) overdose. Cochrane Database Syst Rev. 2018, 2:CD003328. 10.1002/14651858.CD003328.pub3

9. Park BK, Dear JW, Antoine DJ: Paracetamol (acetaminophen) poisoning. BMJ Clin Evid. 2015, 2015:2101.

10. Serjeant L, Evans J, Sampaziotis F, Petchey WG: Haemodialysis in acute paracetamol poisoning . BMJ Case Rep. 2017, 2017:bcr2016218667. 10.1136/bcr-2016-218667

11. Raina R, Grewal MK, Blackford M, et al.: Renal replacement therapy in the management of intoxications in children: recommendations from the Pediatric Continuous Renal Replacement Therapy (PCRRT) workgroup. Pediatr Nephrol. 2019, 34:2427-2448. 10.1007/s00467-019-04319-2

12. Bhushan B, Apte U: Liver regeneration after acetaminophen hepatotoxicity: mechanisms and therapeutic opportunities. Am J Pathol. 2019, 184:719-729. 10.1016/j.ajpath.2018.12.006 